\title{
Experiencing Male Dominance in Swedish Film Production
}

\author{
Maria Jansson and Louise Wallenberg
}

\section{INTRODUCTION}

Sweden as a film nation has attracted international attention for its recent success in increasing the number of female directors, scriptwriters and producers. ${ }^{1}$ The efforts undertaken by the Swedish Film Institute (SFI) on the matter of gender equality, most notably the goal of a 5050 distribution, reached a peak in 2016 when film productions supported by public funding reached the goal of at least $50 \%$ women in all these positions. This peak must be interpreted as the culmination of a long struggle

The original version of the chapter "Experiencing Male Dominance in Swedish Film Production" was inadvertently published non-open access. It has now been changed to open access under a CC BY 4.0 license and the copyright holder has been updated to "The Author(s)". The book has also been updated with this change.

\footnotetext{
M. Jansson ( $\bowtie)$

Department of Political Science, Stockholm University, Stockholm, Sweden e-mail: maria.jansson@statsvet.su.se

L. Wallenberg

Film and Fashion Studies, Stockholm University, Stockholm, Sweden e-mail: louise.wallenberg@ims.su.se

(C) The Author(s) 2020, corrected publication 2020

S. Liddy (ed.), Women in the International Film Industry, https://doi.org/10.1007/978-3-030-39070-9_10
} 
for gender equality, initially driven by women film workers who have organized since the 1970s, and since 2000 promoted by government issued policies. Despite reaching the 5050 quota, several scandals regarding discrimination have occurred recently. In that same peak year, 2016, SF Studios-one of the major film-producing companies in Sweden, and with a history dating back to the late 1910s-was shaken by a series of revelations of overt sexism (Boger 2016). And similar to many other countries (see, e.g., Rich 2018; Cobb and Horeck 2018; Sorensen 2018), the \#metoo movement in Sweden would soon disclose the extent of sexual harassment in the film and TV industries. These events display a lacuna in the gender equality efforts and suggest that gender equality in numbers may not be enough to transform the working conditions of women film workers to the extent that is often assumed.

However, the long tradition of government-initiated gender equality measures and a well-established public discourse on gender equality, along with high numbers of women behind the camera, make the Swedish film industry an ideal case for a novel approach to studying gender equality: to analyze women's experiences of working in a film industry where gender equality efforts have been implemented.

Previous studies of gender equality in the film industry have contributed with various quantitative measures of the number of women in different positions, as well as differences between women and men regarding budget size, ticket sales, quality of networks, etc. (see, e.g., Bielby and Bielby 1996; Grugulis and Stoyanova 2012; Smith et al. 2013; Lauzen 2019). Other studies have focused on impediments to gender equality such as conflicts with women's care work and the dominance of men in decision-making positions (Sørensen 2010; Mark 2006). However, little is known about how gender equality measures actually affect women's everyday experiences in the film industry. Based on in-depth interviews with women film workers, this chapter takes an overarching grip on the current state of gender equality in the Swedish film industry. We depart from the theoretical assumption that rules and norms governing the film industry, including those connected to gender equality reforms (Jansson 2016, 2017), provide an institutional context within which film workers have to navigate in their work. The aim of our chapter is to investigate how women film workers experience their day-to-day practice in an industry where gender equality has been promoted for almost 20 years. We are interested in knowing what institutional arrangements give rise to opportunities or problems, and in what way women's experiences give rise to counterstrategies and resistance. 


\section{Gender ANd The Swedish Film Industry}

Government support has provided an important contribution to the funding of film productions since 1963 when a film support scheme ("Filmavtalet") was introduced. In 2000, the government tasked the Swedish Film Institute to promote gender equality, and in 2006, a formal goal of an equal share of women and men on the key creative roles of director, scriptwriter and producers was set. Despite the fact that this goal was inserted in an agreement signed by representatives of the film industry, several industry stakeholders considered it to be in conflict with already existing objectives to produce quality film that reached a considerable number of ticket buyers. Media coverage reveals how some industry representatives and journalists have argued that gender equality is counterproductive to producing quality film (see, e.g., Nordström 2015). Others argue that women film workers have to stop whining and do their thing instead of leaning on gender-specific benefits (see, e.g., Sigander 2010). The CEO of the Film Institute, Anna Serner, has been targeted in media for promoting "quotas" before quality, and editorials have argued that her gender "stalinism" endangers the arms-length principle in cultural policy (see, e.g., Helmersson 2018). To conclude, as the number of women behind the camera has increased in Sweden, so has the critique of the gender equality measures. In this context, it is interesting to note that the first three among the top ten Swedish films in the Swedish Film Institute's quality ranking since 2007 have a woman as director: Amanda Kernell's Sami Blood/Sameblod (2016), Anna Hodell's The Reunion/Äterträffen (2013) and Lisa Aschan's She Monkeys / Apflickorna (2011) (SFI 2019).

While being contested, the gender equality reform has led to an increase of women behind the camera in the three key creative roles: director, scriptwriter and producer. In feature-length fiction, the average share of women directors and scriptwriters in 1996-1999 was 20\% and producers $16 \%$ (SFI 2008), and in 2013-2017, the average share of women was $38 \%$ directors, $34 \%$ scriptwriters and $52 \%$ producers. The figures vary over the years, and the share of directors hit an all-time low of $7 \%$ in 2012 and an all-time high in 2017 with $40 \%$ women directors in all feature-length fiction film releases (SFI 2018; see also Fig. 1). Films with production support from the Swedish Film Institute have generally done better in terms of share of women behind the camera than films without such support. In absolute numbers, feature-length film releases in Sweden have varied between 40 and 50 per year since 2000 , including both fiction and documentaries, which means that in the peak year of 2017, 10 out 
Share of women in key creative roles, percentages of all films released each year

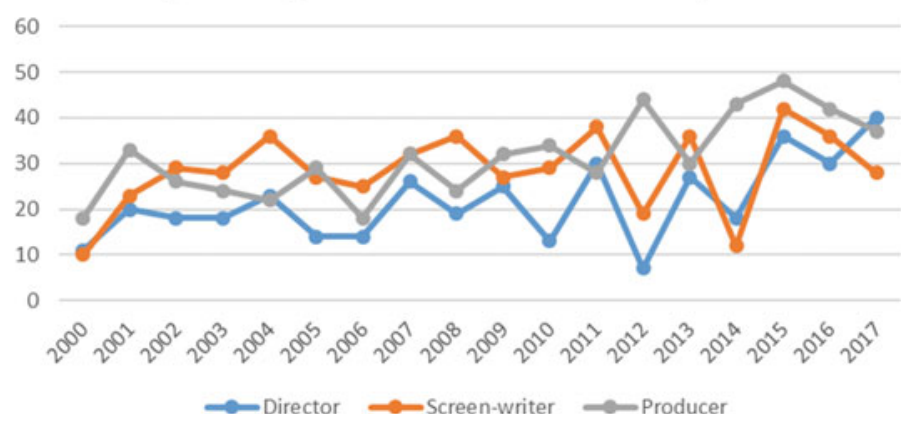

Fig. 1 Graph of share of women in creative roles, percentages of all films released each year (Sources SFI 2008, 2012, 2017)

of 25 fiction films had a woman director, and in 2012, only 2 out of 30 fiction films had a woman director.

Regarding budgets, feature-length fiction films with women directors between 2013 and 2016 had on average a budget ranging between 66 and $86 \%$ of the budget for films with a man as director. For documentaries, a slightly different pattern emerges where films with women directors sometimes have larger budgets than those with men directors, and films with women directors range from 72 to $115 \%$ of the budgets for films with men directors (SFI 2013, 2014, 2015, 2016a). However, on average, the Swedish Film Institute concludes: "In all key functions women generally have overall lower budgets than men" (SFI 2018, p. 17). Most significantly, the largest effect on difference in budgets depends on the gender of the main protagonist: films with a male lead have on average a $33 \%$ higher budget than films with a woman lead.

Films with women in any key creative role have also significantly lower budgets for launching which means that women's films are distributed in fewer cinema theaters and hence attract fewer ticket buyers. The distribution of films with female directors is more likely to be made by distributors focusing on so-called quality film, like the non-for-profit distributor Folkets Bio, who has a large share of films with women directors and women protagonists (Jansson and Bivald 2013; SFI 2018). 


\section{INSTITUTIONS AND EXPERIENCES}

In order to analyze women's experiences and how they are related to film policy, we turn to feminist institutionalism. Institutional theory defines institutions as formal and informal rules, norms and praxis that govern an organization or a field, in our case the Swedish film industry. Feminist institutionalism is used to understand how norms and rules affect gender relations, and how they change, most commonly due to gender equality reforms (Krook and Mackay 2010). A basic assumption in feminist institutional theory is that all institutions and organizations are gendered. This is to say that gender equality reforms do not create gender relations; rather, they aim to change already established gender relations and patterns (see, e.g., Mackay 2014).

In a previous study, Jansson has pointed to concerns regarding the design of Swedish gender equality reforms, for instance that they were limited to targeting an increase in the number of women, arguing that this would also affect working conditions and the content of films, and that the reforms were not anchored among the stakeholders in the industry (Jansson 2016). In addition, rather than transforming policy, gender equality was added to previously existing norms. These factors have affected the possibilities for the reforms to reshape gender relations, as they increased their "nested newness," i.e., the risk of being trumped by other values or routines (Skeije and Teigen 2003; Mackay 2014). The reforms have also produced dilemmas and paradoxes which women film workers have been forced to handle. For instance, individual women are often portrayed as tokens of gender equality, or seen as representatives of their gender, rather than as individual filmmakers (Jansson 2017). This means that women constantly have to deal with how to work in, relate to, and navigate an industry that is formed by long-standing male dominance, but at the same time is constructed as gender equal.

To explore the ways women experience this situation, we have interviewed 21 women active in the film industry in various positions: directors, scriptwriters, actors, producers and continuity supervisors. The interviews took place either at our office at the Department of Media Studies, conveniently located in Filmbuset, which is a well-known venue for all Swedish film workers (and where the Swedish Film Institute is seated), or at a venue chosen by the interviewee. The interviews lasted on average around one hour and 15 minutes, but they varied between 
50 minutes and three hours. The interviews were recorded and transcribed. All interviews were made in Swedish, and we are responsible for the translation of the quotes used in this text. To provide background and context, we use public record material as well as policy documents and statistics from the Swedish Film Institute.

Allowing the experiences of women film workers to be the starting point for an analysis of the Swedish film industry means that we let their everyday observations set our agenda, and that we theorize their experiences in order to understand how the current institutional setup is reflected in their day-to-day lives (see Smith 1987). Working with the interviews, we realized that many of the women were-explicitly or implicitly-telling us about strategies they had developed. These strategies were based on previous experiences and an acquired "sense" of how the film industry works. Hence, identifying strategies could be used to understand how different official and unofficial institutions, i.e., norms, rules and regulations, play out in gendered ways.

Below, we present three themes that were frequently addressed in the interviews. The first theme deals with the interviewees' experiences of portraying a female protagonist; the second theme deals with gendered experiences from being on the set; and the third theme deals with experiences of funding film production.

\section{Negotiating Female Protagonists}

The interviewed women experience a constant questioning of why they want to focus on women in their films. A senior interviewee tells a story about how the first CEO of the Swedish Film Institute, Harry Schein, resented her first film, because "who would want to see a film about two ladies in their 60s?" As the film went on to win a price at the Cannes festival (1977), and was sold to fourteen countries overnight, Schein had to swallow his pride and host a reception. Another director tells us about how she was criticized for excluding male characters from her film. This was her first film, featuring four young women of different ethnicities in key roles. While there are two male characters, the protagonist's intimate relationships are all with other women. As the film was being discussed with financers and producers, the question was if it should be marketed as an "all-women" film, and the male characters removed, or if more men should be added to make the film more mainstream. Her choice to keep the two men was conscious, but nevertheless provocative: "There 
are men, but apparently not enough," she tells us, yet, for her, "this film didn't need any more men."

Adding to the problem of making films about women, many of the interviewees tell stories about getting comments on the way they wanted to portray their female characters. While they strived to make their women protagonists into complex individuals, financiers, producers and distributors would question their decisions and request more stereotypical portrayals. One director tells us how she had been involved in strenuous discussions regarding the female protagonist in her most recent film, and concludes:

Well, generally, women characters are being questioned so much more, but that is because men have a much bigger register of accepted behaviors and expressions. It is very much about the woman being likeable, someone [a man] has to be interested in her.

Likeability also spilled over in the choice of actor: the producer emphasized the importance of her being sexually attractive, and here, our interviewee had to give in. Yet, during the discussions about the script and the character development, she met a lot of resistance regarding the female protagonist's sexual history: “They just couldn't take that the protagonist had had four abortions, it was as if that was completely unthinkable for a ballet dancer." Another director describes how her protagonist was not considered credible when yelling at her boss, and how depictions of female friendship had to follow a specific script to be considered reasonable.

A director/scriptwriter who has made some 20 films encountered a related, but different, problem. In her most recent film, she uses a female voice-over who speaks to and interacts with the male character. When applying for EU funding, the committee dismissed her application with the argument that "the [female] voiceover was provocative and bossy, and they felt sorry for the poor man who was controlled by this voice." This suggests that a female character is expected to be portrayed as submissive (or at least relatively subjected) to the male characters on screen, and to depict (or in this case use a voice of) a woman that breaks with current conventions makes it more difficult to finance the film.

Several of the interviewees work to avoid sexualizing and objectifying female characters and talk about how they want to create a safe space for women actors. They need to feel comfortable during shooting and 
once the film is being screened. Such care not to sexualize women may, however, be understood as making the film less attractive. As the director who applied for EU funding was told when applying for funding from the French Film Institute, the film did not "visually exploit the fact that one of the characters was a prostitute. I didn't show her naked in the film."

There seem to be certain fixed notions about how women on screen must be presented in order to pass as credible and likeable. Representations of women are circumscribed by a (hetero)normative mind-set that dictates that female characters must be emotionally credible and submissive, or at least subjected, in relation to men on screen. A female protagonist also has to be desirable and sexually available for the male character. More than 40 years after the first wave of feminist film criticism unpacked the sexist and misogynist stereotyping governing mainstream cinema (Rosen 1973; Haskell 1974; Mulvey 1975), women protagonists are still being circumscribed and delimited under the umbrella of female likeability. Women on screen have to be likeable because financers and producers believe that this is what the audience wants. Regarding the norms for portraying women, gender equality efforts have so far fallen short. Wanting to depict complex female characters is obviously still difficult.

\section{ON THE SET}

A quite different topic is how women experience the production site. Long hours on the set are difficult to combine with caring for children, and one of the directors had decided to work shorter days in order to make life more reasonable. She was a single mother when she made one of her films and it just was not possible to work long hours. However, the decision to cut hours had economic consequences: "And then, how can we afford that? Well, let's take out some shots to make it cheaper. We can use more black frames instead!" This solution was in line with the aesthetics she used and was a creative way to make ends meet in the private sphere and on the set. However, it is also an example of how women resist complying with established norms.

As to the work environment on site, a former director, now involved in film education, tells us that the film set is (still) a "playground for the chaps," and several of the interviewees speak of different kinds of unwanted sexual attention. For a director, as for all professions demanding authority, sexual attention is problematic, not only for being 
unwanted, but also because it undermines authority, control and agency, since the construction of heterosexual relations renders women as objects and as subjected to men. In her book Ravinen (2007), director Lisa Ohlin writes about the way her authority was questioned on set, as for example, via deep sighs, rolling eyes, but also, of how one actor once grabbed his "package" when receiving instructions from her. We understand these examples as demonstrations to restore male superiority on a set led by a woman. This kind of behavior is discussed in several interviews and is often explained in terms of the actors' vulnerability on the set. Actors are exposed to intense visibility and they know that large audiences may see the result. In addition, they are often being corrected by the director and others, leading to repeated takes. This renders them vulnerable and is thus interpreted as a mitigating circumstance when talking about (male) actors (harassing) behavior toward their colleagues in the crew. However, cross-read with dominant ideas about men as being in charge and as holders of the gaze, the descriptions of vulnerability reveal how male actors on a film set with a woman in charge are deprived of core masculinity features. Hence, challenging women directors' authority can be understood as a way to reclaim masculinity.

The many strategies developed and deployed by women to counter challenges to their authority reveal how constructions of femininity are opposed to authority, and how attributes of femininity such as pleasantness and emotionality must be hidden: "I try to be grumpy, not to smile," says one director. She tells us that presenting herself as unavailable is an effective way of making people follow her lead. The same director says that she can get very emotional at times when a scene turns out well, and that she then asks her cinematographer to step in to talk to the crew. She does not want them to see how affected she is, because that would put her authority at risk. These strategies are examples of hiding behaviors that may be interpreted as feminine and thus as signs of weakness. Other strategies make use of the current constructions of gender norms. For instance, one of the interviewees says that she allows men to think they are in charge, when they actually are not: "I may find ways to make them think that it was their idea." This strategy seemingly contradicts the idea of authority, while it demonstrates the need to be pragmatic in order to make the crew do as you want.

A third category of strategies is to speak up and explicitly address anticipated or experienced problems, and one example is the publication of the book, Ravinen, quoted above. Another example is the director who tells 
us that she has decided to make a "list of rules to follow" to be distributed to the crew for her next film project. This, she says, is a measure of prevention. Hence, she expects to encounter certain problems and chooses to formulate and make her expectations explicit to the crew by distributing the list. To explicitly address work environment problems, in a book or by a list, is also an effort to change and resist the norms developed as a result of a long-standing male dominance.

\section{FUNDING}

While stories about how to depict women and how to navigate on the set are quite similar among the interviewees, the topic of funding displays more varied experiences. Several interviews address the question of economic survival. "You have to work a lot for free," one filmmaker says, pinpointing an experience shared by many. How to get by, and to support children, is a constant worry, and many interviewees have jobs on the side. A different, but equally important, problem is to garner funds to finance film projects. A director, who has been making low-budget films since the early 1970s, puts it in clear text when she says: "It is getting the dough that is the problem!”

One interviewee tells us that she has “... produced films by the credit card model ... that is, I always had a new film in the loop in order to pay for the previous one." She also discusses how policy and technical development have changed film economy: "In the 1970s, we owned our own companies and had control over our resources." According to her, the dependency on financiers has increased, a fact that also affects what kind of films will be produced. The relation between funders and filmmakers is also discussed in terms of budget size. Everyone seems to agree that the smaller the budget, the greater the freedom: "It is a low budget film ... they have not put in so much money, so they are not allowed to decide that much." Another director, working with larger budgets, corroborates this belief when she tells us about how the producer of her most recent film withheld information about the finances, which made it difficult for her to adjust the film to the budget, while still maintaining her own artistic voice.

These examples indicate that funding is closely related to the way that projects are run. In some projects, the director has participated in everything from fundraising and script writing to post-production and distribution. However, we have also interviewed directors who have 
mainly worked in big productions headed by large production companies. These directors are contacted when a script and funding already exists. One of these, a director who has made several feature films, tells us that her part in fundraising is to sit in on meetings with the Swedish Film Institute to "assure them that the film will be realized with quality." Her name and experience contribute to sealing the deal with the Swedish Film Institute.

Most women involved in raising money pinpoint how this is complicated, but we have noted a difference where the more senior women seem to have a particularly difficult time to get money to do their next film. Several of them have encountered the argument that they are not granted money because the film they want to do is just a repetition, accusing them of doing the same film over and over again. Some interviewees bring up ageism and believe that it is because of them now being "old women [hags]," that they are being excluded. They have been successful as directors, making several critically acclaimed films, and some have also occupied important positions (e.g., as commissioner at the Swedish Film Institute), yet they are now "precluded." Several of our senior interviewees have worked with public service TV (SVT) and relied on them for funding, but now, they say, "SVT is not interested." These experiences reflect a number of the organizational changes that have occurred during the last couple of decades: the increased importance of commercial values at the expense of critical documentaries and art film; the fact that larger production companies have consolidated their presence by buying smaller companies, a process that also has been endorsed by Swedish film policy (Jansson and Bivald 2013); and the status between TV and film has changed in favor of television. As one of our interviewees argues, nowadays the big money is in TV series and that: "television is the new male bastion, most TV-series have male conceptual directors." In addition, the gender equality measures have often favored younger talents.

Combined, these changes favor a specific type of content, which requires a specific type of filmmaker: "you must be able to tell stories like The Wire or Bron (The Bridge), i.e. the sellable stuff." In an environment where films with women as protagonists or directors are not considered to attract large audiences, these developments erode the funding possibilities for women who insist on producing critical documentaries or more artistic films. As the Swedish Film Institute to an extent focuses on new, young talents, senior women have an even harder time. 


\section{Concluding Remarks}

This chapter has discussed the experiences of women film workers in Sweden, often described as the most gender equal film industry in the world. The aim was to explore the relation between women's experiences and the institutional context as well as to identify women's counterstrategies and resistance. In this section, we want to summarize by highlighting the links between the three themes-the female protagonist, experiences on the set and funding - and relate our results to the three gender equality goals: increased share of women behind the camera; portraying women and women's stories on screen; and improving women's working conditions in the film industry. We also want to address the counterstrategies and resistance deployed by the women we have interviewed.

The interviewees' experiences reflect different developments in the film industry that have produced an institutional environment, which promotes a specific kind of film as well as a certain type of filmmakers (see also Neale 1981). As this chapter has shown, the women filmmakers who wish to portray women in complex and new ways, and counter to current conventions, experience problems. In addition, a female protagonist is linked to lower budgets, fewer screenings, lower PR budgets and less audience. Further, most of the interviewed women have experienced their authority on the set being challenged because of their gender. Oftentimes, the challenges are expressed through sexualized demonstrations, used to reclaim male supremacy. The vulnerability of women's authority on the set increases due to changes in the power relations in the industry as large production companies and distributors have gained greater power. These general changes are also reflected in the gender equality work, for instance, in the recent efforts to have more women in key creative roles in film projects with the largest budgets (SFI 2016b). However, our interviews indicate that larger budgets mean circumscribed artistic control and lesser possibilities to break conventions. Hence, including women in more commercial productions will potentially increase the numbers of women behind the camera, but will not necessarily show women's experiences and change the representations of gender on screen, nor will it automatically lead to better working conditions for women.

The gender equality efforts, as such, are also challenged by the developments in the industry. First, larger and stronger production companies, in combination with television's increasing power, make the position of the Swedish Film Institute relatively weaker. This in turn impedes the 
organization's possibilities to enforce gender equality reforms. Second, gender equality efforts have so far not been able to change the norms in the industry regarding how gender should be portrayed on film, nor to change the macho culture on the set. However, the Swedish Film Institute and its gender equality work have been able to increase the number of women behind the camera. Additionally, gender equality measures have contributed to the development of small "pockets" in film production where women filmmakers are able to develop new narratives and new ways of displaying gender on screen. In these productions, women have also the possibility to set their own terms for how they want to make films.

The difficulties that women filmmakers encounter when wanting to represent gender differently indicate that they challenge current norms and conventions regarding how gender should be portrayed. So, too, do the strategies they deploy for creating a reasonable work environment on the set. Some of these strategies are developed for mere survival, and others are explicitly forward aiming. All of them hold the potential for change. Speaking up and addressing problems is one important strategy for change. Adjusting work hours to personal needs, rather than budgetary restrictions, runs counter to ideals of flexibility and the idealization of long working hours on the set as necessary for the artistic process. Arguing that running out of money means putting in more black frames in the film rather than working more hours without pay is a way to make harsh reality meet aesthetic development. However, resisting current norms has a price. Defying established ways to portray women causes problems with funding and voicing problems and injustices may lead to being ignored and excluded from new projects. Senior women who insist on working with films containing critical messages, or tell stories based on their own experiences, are continuously being rejected for not conforming to new ideals. However, we would like to argue that it is exactly in all of these unruly practices, undertaken by women who continue to struggle, that the hope for gender equality rests.

\section{Note}

1. This article is part of the project Representing Women: Gendering Swedish Film Culture and Production, funded by Riksbankens Jubileumsfond-The Swedish Foundation for Humanities and Social Science, Project No. P17 0079:1. 


\section{REFERENCES}

Bielby, D. D., \& Bielby, W. T. (1996). Women and Men in Film: Gender Inequality Among Writers in a Culture Industry. Gender and Society, 10(3), 248-270. https://doi.org/10.1177/089124396010003004.

Boger, L. (2016, June 9). Machokultur får kvinnor att lämna SF-Studios [Machoculture makes women leave SF-Studios]. Aftonbladet.

Cobb, S., \& Horeck, T. (2018). Post Weinstein: Gendered Power and Harassment in the Media Industries. Feminist Media Studies, 18(3), 489-508. https://doi.org/10.1080/14680777.2018.1456155.

Grugulis, I., \& Stoyanova, D. (2012). Social Capital and Networks in Film and TV: Jobs for the Boys? Organization Studies, 33(10), 1311-1331. https:// doi.org/10.1177/0170840612453525.

Haskell, M. (1974). From Reverence to Rape: The Treatment of Women in the Movies. London: New English Library.

Helmersson, E. (2018, January 3). Ledare: Normkritiken tar över kulturen och ingen vågar klaga [Editorial: Norm-Critics Take Over Culture, and No One Dares to Complain]. Dagens Nyheter.

Jansson, M. (2016). The Quality of Gender Equality: Gender Quotas and Swedish Film Governance. International Journal of Cultural Policy, 25(2), 218-223. https://doi.org/10.1080/10286632.2016.1248952.

Jansson, M. (2017). Gender Equality in Swedish Film Policy: Radical Interpretations and 'Unruly' Women. European Journal of Women's Studies, 24(4), 336-350. https://doi.org/10.1177/1350506817692387.

Jansson, M., \& Bivald, K. (2013). What a Sad Story: On Distribution, Production and Gender Equality in the Film Industry. Stockholm: Wift.

Krook, M.-L., \& Mackay, F. (2010). Gender, Politics and Institutions: Toward a Feminist Institutionalism. Basinstoke: Palgrave Macmillan.

Lauzen, M. M. (2019). It's a Man's (Celluloid) World: Portrayals of Female Characters in the Top Grossing Films of 2018. Retrieved from https://wom enintvfilm.sdsu.edu/wp-content/uploads/2019/02/2018_Its_a_Mans_Cel luloid_World_Report.pdf.

Mackay, F. (2014). Nested Newness, Institutional Innovation, and the Gendered Limits of Change. Politics and Gender, 10(4), 549-571. https://doi.org/10. $1017 /$ S1743923X14000415.

Mark, E. (2006). Att Göra Som Man Brukar. Om Beslutsprocesser i Filmbranschen [To Do the Way It Has Always Been Done. On Decision Making Processes in the Film Industry]. Stockholm: Wift Sverige.

Mulvey, L. (1975). Visual Pleasure and Narrative Cinema. Screen, 16(3), 6-18. https://doi.org/10.1093/screen/16.3.6.

Neale, S. (1981). Art Cinema as Institution. Screen, 22(1), 11-39. https://doi. org/10.1093/screen/22.1.11. 
Nordström, A. (2015, November 27). Många kritiska roster mot Filminstitutets identitetspolitik [Many Critical Voices Against the Identity Politics of the Film Institute]. Dagens Nyheter.

Rich, R. B. (2018). She Can Do It! Film Quarterly, 71(3), 5-9. Retrieved from https://filmquarterly.org/2018/02/28/she-can-do-it/.

Rosen, M. (1973). Popcorn Venus: Women, Movies and the American Dream. New York: Coward, McCann \& Geoghegan.

Sigander, M. (2010, November 2). Nu kommer vi 70-talister [Here We Come, the 70 s Generation]. Expressen.

Skeije, H., \& Teigen, M. (2003). Men imellom. Mansdominans og likestillingspolitikk. Den norkse maktutredning [Between Men. Male Dominance and Gender Equality Policy. The Norgwegian Committee on Power Distribution]. Oslo: Gyldendal.

Smith, D. (1987). The Everyday World As Problematic: A Feminist Sociology. Boston: Northeastern University Press.

Smith, S. L., Choueiti, M., Scofield, E., \& Pieper, K. (2013). Gender Inequality in 500 Popular Films: Examining On-Screen Portrayals and Behind the Scenes Employment Patterns in Motion Pictures Released between 2007-2012. Los Angeles: Annenberg School for Communication \& Journalism, University of Southern California.

Sorensen, I. (2018). What Sexual Harassment in Zentropa Tells Us About Cultural Policy Post-Weinstein. Feminist Media Studies, 18(3), 502-505. https://doi.org/10.1080/14680777.2018.1456165.

Sørensen, S. (2010). Ta alle talenterne $i$ bruk! Utjevningsforslag for balansert kjønnsrepresentasjon $i$ norsk filmbransje [Make Use of All Talents! Gender Equality Suggestions for Gender Representation in the Norwegian Film Industry]. Oslo: Kulturmenglarne AS.

Swedish Film Institute (SFI). (2008, 2012, 2013, 2014, 2015, 2016a). Facts and Figures. Stockholm: SFI. Retrieved from https://www.filminstitutet.se/ en/learn-more-about-film/statistics/publications $2 /$.

Swedish Film Institute (SFI). (2016b). Goal 2020: Gender Action Plan. Retrieved from https://www.filminstitutet.se/globalassets/_dokument/han dlingsplaner/actionplan_genderequality_eng_final.pdf.

Swedish Film Institute (SFI). (2017). Looking Back and Moving Forward: Gender Equality Report 2017. Stockholm: SFI. Retrieved from https:// www.filminstitutet.se/globalassets/2.-fa-kunskap-om-film/analys-och-statis tik/publications/other-publications/swedish-film-insitute-gender-equality-rep ort_2017_eng.pdf.

Swedish Film Institute (SFI). (2018). The Money Issue: Gender Equality Report 2018. Retrieved from https://www.filminstitutet.se/globalassets/2.-fa-kun skap-om-film/analys-och-statistik/publications/other-publications/sfi-gen der-equality-report-2018-lowres.pdf. 
Swedish Film Institute (SFI). (2019). Betygsindex Svensk Film. Retrieved from https://www.filminstitutet.se/sv/fa-kunskap-om-film/analys-och-statis tik/betygsindex-svensk-film $2 /$.

Open Access This chapter is licensed under the terms of the Creative Commons Attribution 4.0 International License (http://creativecommons.org/licenses/ by $/ 4.0 /)$, which permits use, sharing, adaptation, distribution and reproduction in any medium or format, as long as you give appropriate credit to the original author(s) and the source, provide a link to the Creative Commons license and indicate if changes were made.

The images or other third party material in this chapter are included in the chapter's Creative Commons license, unless indicated otherwise in a credit line to the material. If material is not included in the chapter's Creative Commons license and your intended use is not permitted by statutory regulation or exceeds the permitted use, you will need to obtain permission directly from the copyright holder.

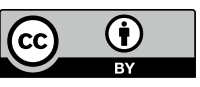

